\title{
Art and Fear of Propaganda
}

\author{
STEVE LAMBERT
}

Associate Professor of New Media, State University of New York at Purchase College

\begin{abstract}
Concerns about artwork that aims to impact power, "turning art into propaganda," not only misunderstand how propaganda works in contemporary society, but also privilege a view of art and art's role that favors the wealthy and powerful.
\end{abstract}

You likely already know this Trotsky quote:

"Art is not a mirror held up to society but a hammer with which to shape it."

You may have heard it attributed to Vladimir Mayakovsky or Bertolt Brecht, or referenced in books by Paulo Freire and in the opening credits of a documentary on Pussy Riot.

Potentially, Trotsky's statement would have put to bed powerful myths about the role of art in society decades ago, but it remains relevant in the twenty-first century because a dominant, contrasting sentiment also lingers: real art and artists shouldn't have to sully themselves in the messy, ugly world of contemporary politics. This argument suggests that art is about exploring ideas. Art deals in abstract concepts and aesthetics. It's about beauty, form, and escape. A focus on the everyday world - and more specifically, shaping real, tangible outcomes in that world — only limits an artist and their creativity, and artists' skills aren't well equipped to achieve activist objectives anyway. The concern is that if we don't help shield and protect our precious artists from politics, their work will be instrumentalized by outside forces. Artists will be manipulated; they'll make bad art_ - or worse, propaganda.

Making art that aims to impact power over the last twenty years, I hear more than my share of kindly-worded warnings about instrumentalizing art.

Whenever I speak about art and activism there's someone in the room who gets troubled - they wring their hands, furrow their brow, and imagine that aiming for outcomes that impact power will negate the freedom and exploration of the creative process. They worry that considering audiences and what they think, feel, and (especially) do in response to an art experience is confining. "But what you're advocating for turns art into propaganda!" 
I'm not so concerned. What follows is my ten-point response to this anxiety, written in a more experimental, and less academic fashion than a journal such as this normally requires (because as we all know, the volume doesn't go up to 10, it goes up to 11).

$* * *$

1. Yes, using art and creativity to shape the world and change it for the better absolutely does instrumentalize that work. But where does the idea come from that this should be shameful and avoided? Think about it: in any other context, the word instrumental is positive.

The surgery was instrumental in the patient's survival.

This volunteer played an instrumental role in the success of the project.

Art is an instrumental tool in changing culture.

But presentations of "art" happen in specific settings. The quiet rooms and white walls of a museum or gallery are designed to isolate our perception of the art works and control the context. This helps the art work become the focus, but art doesn't exist on its own. It's created in a cultural and historical moment and will always be presented in different cultural and historical moments. As much as a museum or gallery itself tries to fade into the background, it is its own context and exists in a system of power, capital, class, education, influence, and persuasion. As much as we collectively pretend they are neutral actors, how art institutions present exhibitions and what is included in them serves an instrumental and didactic purpose and influences audiences as effectively, and much more subtly, than the best propaganda.

2. Let's not pretend fine art exists in some precious domain. We also can't pretend the supposedly apolitical and insulated world of fine art hasn't also, always, been instrumentalized. One simply has to ask, to what end? Making a sculpture that dwells in purely aesthetic or conceptual interests is, intended or not, a tacit political statement. Participating in the art market and museums, even more so. What's called "the art world" is largely a market for luxury goods, consisting of a mix of high-end home decor, financial investments, and an unregulated alternate currency for the wealthy that major museums, commercial galleries, and many artists and institutions all participate in. Art is not free from politics.

3. Art that aims to actually affect power is always up for questioning about whether or not it is, indeed, art. Sure, artists who make snide political commentary seated in a place of detachment will always find a home in the fine art world. But even when art is recognized as "political art," there's a sentiment that, rather than becoming stronger, the mixing of the two contaminates them both. Activist or political art is a bit less-than, or tainted, or a gimmick. Art about politics is grudgingly welcome. Art that impacts power is placed outside the realm. This is likely because art that impacts power is often illegible or ignored- it doesn't make any sense as "art" because it's aiming to achieve other objectives and for a non-art audience.

When art is used to change people's perceptions and behavior and to impact power, a shallow, critical read can link it to a common history with the Nazis' and Stalin's public manipulation and 
mass murder. But this is a selective reading of history using a distorted lens. In our research at the Center for Artistic Activism (https://c4aa.org) on the history of successful social movementsincluding beloved campaigns like Ghandi's anti-colonial independence actions, the Civil Rights Movement, or the United Farmworkers - we found that all successful activism has been artistic activism. For a movement to be successful it requires innovation, cultural relevance, communicating through images, theatre, and performance, and the affective, emotional power of arts and culture. Only after these creative innovations enter the canon, what was once innovative ossifies into standard activist practice. Instead of remembering the Greensboro sit-ins as an innovative, site-specific, loosely scripted but rehearsed, and highly effective, moving performance - which it was - it is remembered simply as an image to be uncritically replicated: a "Sit-In." Another non-violent direct action for the activist toolbox. It undeniably has a place in History, but, for some reason, it finds no place in Art History.

\section{Actions like these that blend artistic methods with activist aims are plainly powerful, so} pretending art isn't instrumental doesn't protect it, it limits its power. Culture shapes societies and our belief in what is and what can be. The cleaving of art from activism and the artificial separation of the two requires a massive and constant collective effort within museums, art schools, galleries, publishers, and others. Of course there's no master plan; it is largely unconscious and goes unnoticed. The whole detachment of fine art from everyday life, the elevation of what is deemed as "Art" within cordoned-off presentations in white-boxes, the dogma that real art is done in isolation, independent of everyday society, and in an orbit above contemporary politics is an effort that takes constant tending, funding, and labor. Billions of dollars over decades. Centuries.

\section{The outsize influence of the capitalist classes driving the global art market certainly benefit} from the belief that art and activism are distinct and separate fields. And especially from the belief that, even when they try, artists just aren't capable of being good at activism. It inherently undermines and declaws creative efforts that may challenge them before they even start. But artists who go along with the myth benefit as well because they are conveniently let off the hook-you can't be expected to take any responsibility when you have already absolved yourself of any agency.

Yet despite all the investment in separating art from activism, these two always seem to want to, naturally, and quite stubbornly, come back together. They are like magnets: keeping them apart takes far more work than allowing them to snap back into place, side by side, as one.

As the Chicano poster artist and an old mentor of mine, Malaquias Montoya, put it to me; art has always been propaganda, it's just mostly propaganda for the rich and powerful.

6. This belief about art becoming propaganda, if and when it aims to achieve real change in the world, misunderstands how art and propaganda work in fundamental ways as forms of communication. You may recognize the Shannon-Weaver model of communication. It's been widely used and taught in communications since it was published in 1949 and has been referred to as the "mother of all models" from which many communications models descend. 


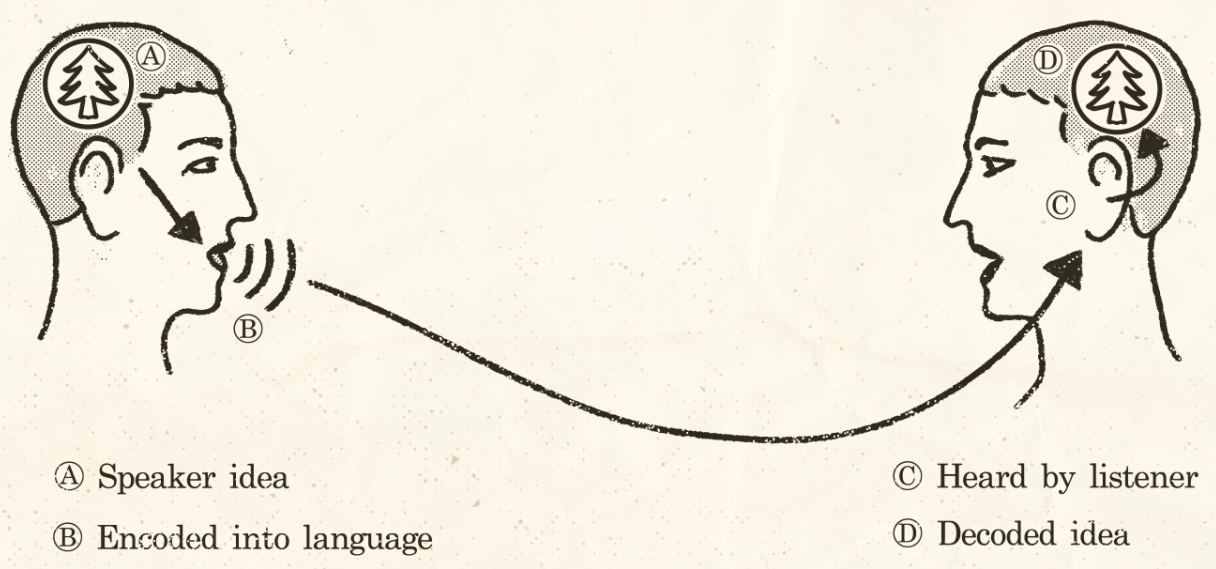

Figure 1. The Shannon and Weaver Model of Communication

In the model, the speaker has a thought, in this example a tree (Figure 1a). They encode that thought into language (Figure 1b) and speak it aloud. Sound travels to the listener's ear (Figure 1c) and is decoded within their brain. When the communication is successful the listener has the same thought as the speaker (Figure 1d). In this model, any deviation between the thought of the speaker and the listener is seen as a failure in communication.

The simplicity of this model makes it quite useful. Other versions add complexity by accounting for noise in the signal, a feedback cycle from the listener, and semantic and audience differences, to name a few.

For our purposes, this simplified version of the mother of all models works elegantly. With one small change, it easily transfers to a child model that helps us visualize the common understanding of propaganda. 


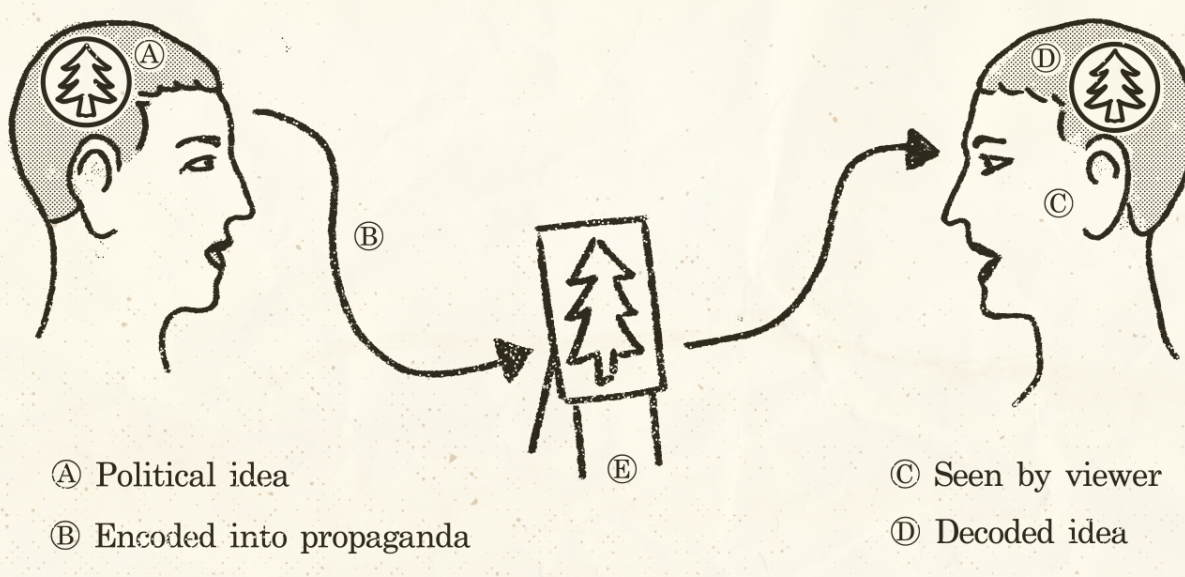

(E) Propaganda

\section{Figure 2. The Duncombe and Lambert Model of Propaganda}

In this 1930s Era Propaganda Model (Figure 2) the message is a political one, encoded into a form of propaganda. Once seen, the propaganda is immediately and unequivocally decoded and understood by the viewer. When the propaganda is successful, the viewer thinks the thoughts the creator of the propaganda imposes upon them.

The fear that art will be turned into propaganda speculates that one simply substitutes art in the place of the propaganda (Figure 2e) in the model. Our culture deteriorates forthwith.

While they may have some similar visual qualities, salt won't take the place of sugar in a recipe. In the same way, when you try to substitute art into the propaganda model, you get very different results. 


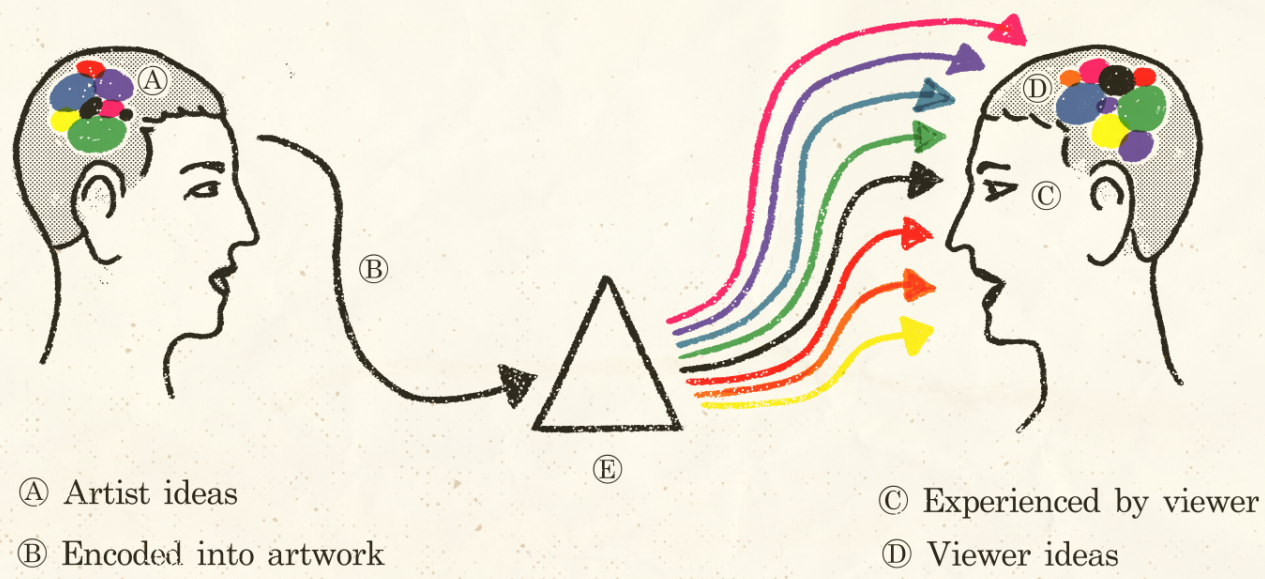

(E) Artwork

\section{Figure 3. The Duncombe and Lambert Model of Artistic Activism}

7. Art functions and communicates differently than propaganda. In the Duncombe-Lambert Model of Artistic Activism (Figure 3), the artist starts with a mix of ideas and concepts (figure 3a). They very consciously encode that into an artwork. When done well, the artwork functions like a prism (figure 3e) - when a focused beam of light enters one side, a rainbow appears on the other. The more focused and intentional the artist is, the more likely a spectrum of meaning radiates out the other side. Those meanings can be serious, ironic, they can conflict and contradict each other, they can offer all kinds of nuance. The viewer experiences these meanings and interprets them, often forming a different mix of thoughts and ideas than did the artist (Figure 3d).

When done well, Artistic Activism does not require a direct one-to-one understanding shared between the artist and the viewer. It accounts for nuance, interpretation, and humanity. For example, a project I led in 2008 created a best-case-scenario replica of the New York Times shortly after Barack Obama's election in which thousands of copies were distributed on the streets of major cities in the United States. Around a decade later, when "fake news" is literally a form of state propaganda, one might wonder what this means for that art work. However, a multi-layered message was embedded in the work - while the surface read as "The New York Times," the headlines, the utopic nature of the stories, and every minor detail, left hints for the viewer that the newspaper was not what it claimed to be at first glance. Readers were not deceived, nor were they meant to be. This form of transparency made that project more effective. The opposite would be true of, for example, of cynical and manipulative "news stories" plainly generated by the Russian Federation's G.R.U. when they were exposed for what they were. The intention and spectrum of meaning and interpretations between art work and propaganda are significantly different. Art works allow for, and can thrive within, this complex multiplicity of meaning and interpretation by the viewer. 


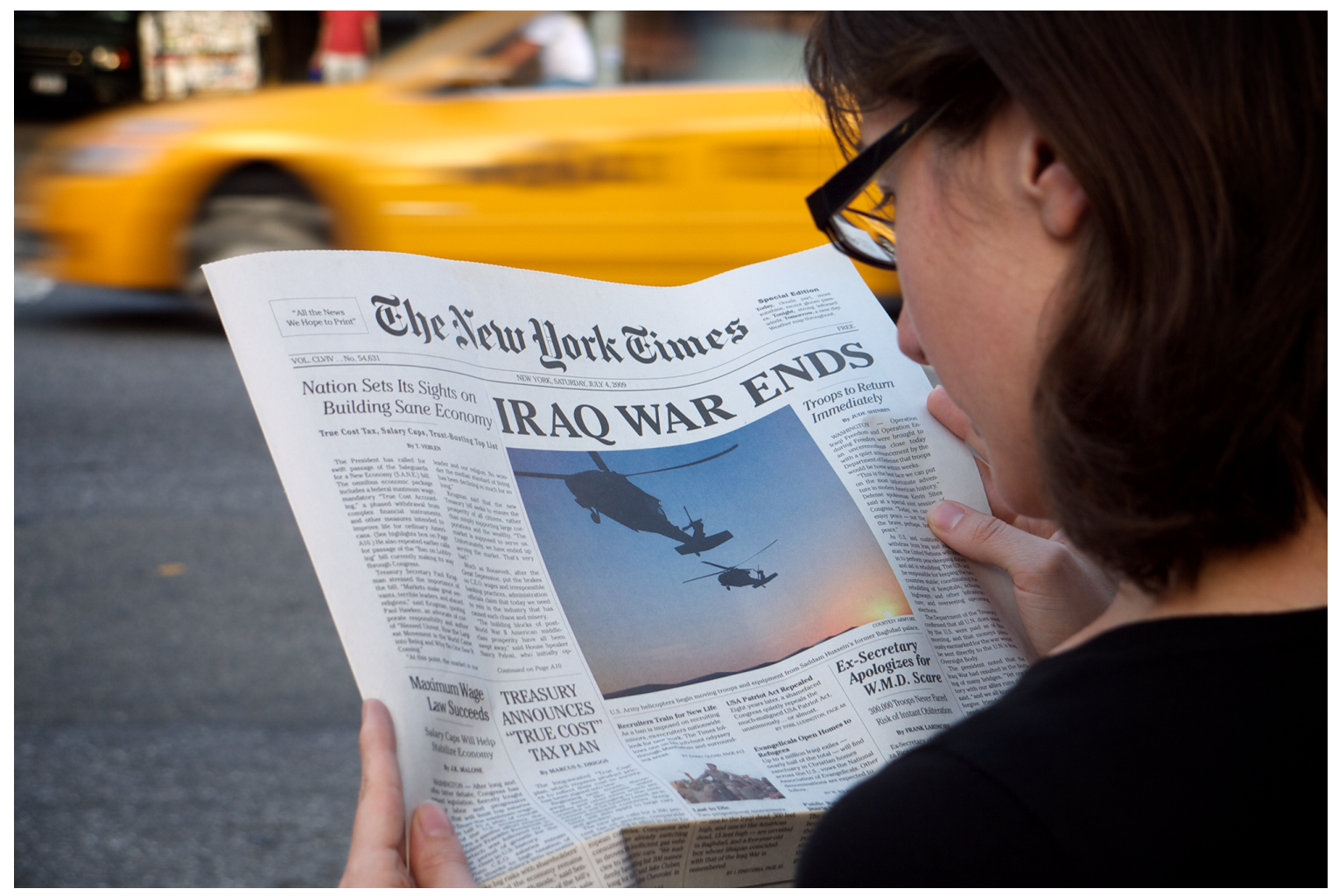

\section{Figure 4. The New York Times Special Edition ${ }^{2}$}

8. When viewers interpret an art work for themselves, the messages are refined by the viewer and become more personally meaningful. More importantly, for a viewer to experience a sense of agency, among those messages can - should - be a relevant call to action for the viewer, so that real change is more likely as a result. One reason art is so effective with activism is that the affective and emotional layers within the message are often what motivate audiences to act.

There's a reason the 1930s Era Propaganda Model is also referred to as the Hypodermic Needle Model (or sometimes the Magic Bullet Model). It's premised on the idea that people can be more than influenced or persuaded; thoughts and actions can be directly injected into a person's mind. Art and Artistic Activism do not work this way. But in many ways, 1930s propaganda never quite achieved this either. The Hypodermic Model was always flawed, but it's also severely outdated.

\section{One should still worry that art will be turned into propaganda, but for very different} reasons: propaganda has changed. In the contemporary United States we have partisan versions of events. There are verifiable events on the news, but depending on how you get your news you may see very different perspectives and emphasis, some going so far as to question whether the events happened. One example was when the Trump administration, just two days after Trump's inauguration, began brazenly claiming there were facts, but their administration had "alternative facts." Republicans make claims without evidence about voter fraud, "illegal voting," and "rigged" elections. In addition we have conspiracy theories that make their way through the culture; the moon landing was fake, the earth is flat, the World Trade Center was blown up by the U.S. Government, Muslims are scheming to implement Sharia Law in the Midwest, high-level 
Democrats run a pedophilia ring out of a D.C. pizza shop, and Coronavirus vaccines make you more infectious, make you infertile, include micro-chips designed by Bill Gates that control your mind, change your DNA, are part of a mass-murder plot, make you magnetic, and on and on.

Russia's propaganda works similarly, and arguably more efficiently and effectively. Their stateowned media and leadership take it upon themselves to strategically distribute multiple perspectives, theories, narratives, and counter-narratives on current events on various state and independent news outlets. One shameless example is their coverage of the shooting down of Malaysian Airlines Flight 17 over Ukraine, in which 298 people were murdered. At first Russia claimed the flight was shot down by Ukrainian military jets. Then, changing stories, they claimed the passenger jet was shot down by a Russian separatist group using anti-aircraft missiles within Ukraine. Then claims were published that the separatist group didn't have anti-aircraft missiles. Then evidence surfaced that Ukrainian anti-aircraft missiles were responsible.

These claims sound plausible, at least, but there were also other theories: Western powers shot down the plane in an attempt to assassinate Putin. The plane was blown up from the inside. No plane was ever shot down and dead bodies were trucked in and placed on a crash site entirely fabricated by Ukrainian officials. The downed plane was not Flight 17, but the missing Malaysian Airlines Flight 370 that disappeared months earlier over the Indian Ocean. Both the Flight 17 and 370 disasters were part of a more elaborate plan by the United States and the CIA. Russia was accused of wrongdoing in order to spoil the World Cup, hosted in Russia that year. The flight was shot down to prevent a cure for AIDS being revealed. Israel was involved. The Illuminati were responsible.

All of these theories were reported. There are active, independent, opposition newspapers in Russia, and even in the above mess of claims, the truth determined by the Dutch-led, international Joint Investigation Team was reported: the passenger jet was shot down by Russian separatists with antiaircraft missiles provided by the Russian military. The truth was not hidden, it was presented out in the open along with more than a dozen other explanations. While Russian citizens did hear the truth, polling revealed that very few believed it. 


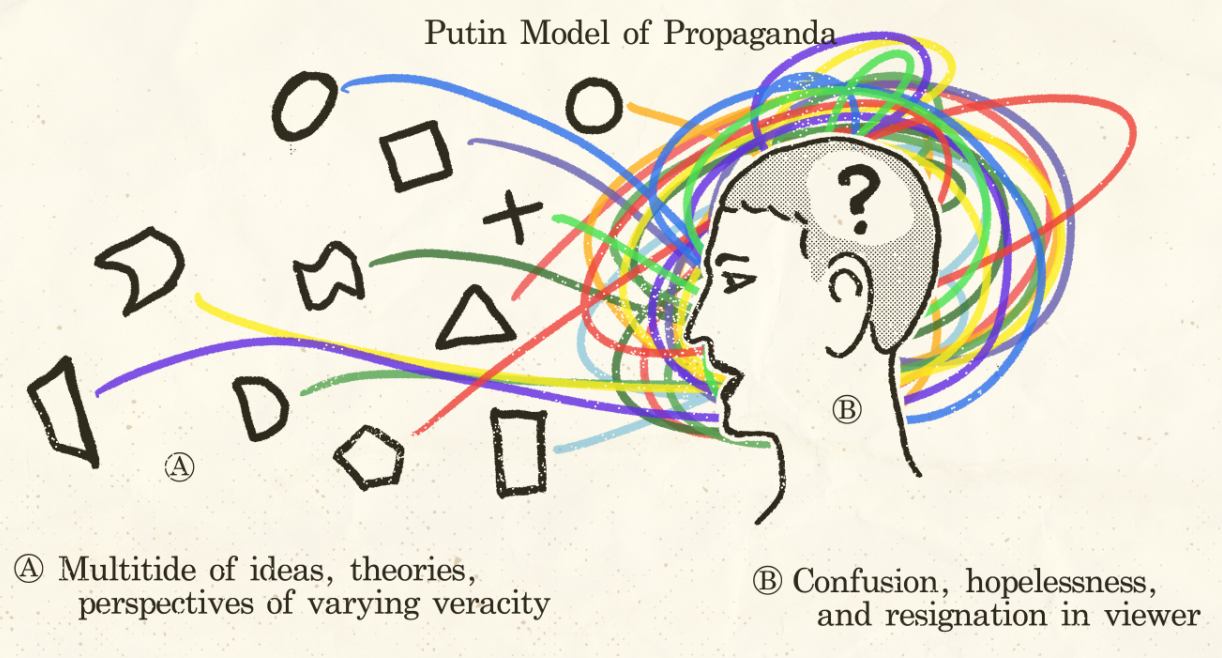

Figure 5. The Putin Model of Propaganda

And with this model it's not so important what, exactly, anyone believes. This propaganda strategy is not to present a totalitarian, official state position that all citizens must have confidence in. Modern propaganda's goal is not for citizens to uniformly mirror back the message of the state. Modern propaganda is the opposite of the Hypodermic Needle. It is, as former Trump advisor Stephen Bannon once put it, "flooding the zone with shit" (Figure 5a). In this way, reality gets lost and loses its importance. Ordinary citizens hear overwhelming amounts of conflicting information and attribute it to the confusing nature of politics itself. Truth and reality become malleable, unknowable. Who can ever say, for certain, what really happened? And if we did, what can anyone really do? And what's the point? It begins to feel like things will always be this way. Apathy and nihilism ascend (figure 5b). All one can do is trust the most convincing politician, shrug, and move on.

Twenty-first-century propaganda's purpose is to generate this overwhelm and resignation in its citizens. Because who benefits from this deluge of perspectives, theories, questions, and verified and unverified, contradictory information? Who benefits from the resulting widespread disengagement from reality? Only the most powerful and the most corrupt.

\section{Where does art that uses politics as its subject matter map onto the modern propaganda} model? Imagine what's typically understood as "political art." It uses a topic that is contentious, but the message is vague and ambiguous. It raises questions and draws connections but doesn't lead the viewer to conclusions. The motivation and rationale are opaque. The artist seeks no concrete, political outcome, only to start a conversation, explore, reflect, or "raise awareness." Does it work? Can it work? 
Make no mistake: we need alternative perspectives, but we can't rely on them alone. We need the truth. The truth is not self-evident. The truth needs help.

This is why the focused intention that enters the prism of artistic activism and the emphasis on concrete outcomes is so important. Because art that trifles with political issues just adds another bit of information to the flood of shit; another perspective, another possibility, or more questions. Or even exposing the truth without pointing viewers to concrete, constructive actions they can take adds to the deluge of overwhelm and cynicism.

11. Artists: don't underestimate your power. Creative freedom is important. Aesthetics are important. As is art that explores, that is personal and internal, that causes awe and wonder. But, especially when wading into social and political issues, artists' efforts can be clarifying, motivating, and transformative. Art, creativity, and culture are profoundly powerful. Artists can take responsibility for that power and have true impact.

N.B. The gravitational pull of the art market and art institutions causes all kinds of distortions in perception that are hard to escape. However, artists should still worry about their art becoming propaganda. Absorbing unfounded fears of 1930s era propaganda, or beliefs that artists aren't suited or should simply avoid directly engaging power, or surrendering their power by presenting a perspective or more information in a flooded information zone, without focused intention or without strategically connecting issues to concrete outcomes and helping people understand the steps they can take to achieve them - their art functions awfully well as modern propaganda.

\section{ACKNOWLEDGEMENTS}

I have worked in collaboration with my fellow co-founder of the Center for Artistic Activism, Stephen Duncombe, for decades, and our ideas about and knowledge of Artistic Activism are forever entangled. Rebecca Bray, our co-director, has helped develop these ideas in various meetings for the organization, or in hotel bars after workshops wrap up. Mushon Zer-Aviv invited me to speak on this topic at the Re:Publica 2018 in Berlin, which forced me to articulate some of these ideas in ways I hadn't before. He also helped proof-read this paper. I'm also indebted to the students and participants in my classes and Center for Artistic Activism workshops, whose questions, responses, and perspective helped inform these ideas.

\section{ENDNOTES}

1. Michael Lewis, “Has Anyone Seen the President?” Bloomberg, February 9, 2018. https:/www.bloomberg.com/opinion/articles/2018-02-09/has-anyone-seen-the-president.

2. Steve Lambert, “The New York Times Special Edition.” Steve Lambert, June 15, 2020. https:/visitsteve.com/made/the-ny-times-special-edition/.

\section{REFERENCES}

Gunter, Joel, and Olga Robinson. "Sergei Skripal and the Russian Disinformation Game." $B B C$ News, September 8, 2018. https://www.bbc.com/news/world-europe-45454142 
Pollock, John. "Russian Disinformation Technology." MIT Technology Review, April 2, 2020. https://www.technologyreview.com/2017/04/13/152305/russian-disinformationtechnology $/$

Reidy, Padraig. "MH17: Five of the Most Bizarre Conspiracy Theories." Guardian News and Media, July 22, 2014.

https://www.theguardian.com/commentisfree/2014/jul/22/mh17-five-bizarre-conspiracytheories-zionist-plots-illuminati-russian-tv

Toler, Aric. "The Weird World of MH17 Conspiracy Theories." bellingcat, July 11, 2017. https://www.bellingcat.com/news/uk-and-europe/2015/08/07/mh17-conspiracies/

\section{AUTHOR BIO}

Steve Lambert has worked alongside artists and activists in twenty countries on four continents, helping them to effect power. Trained in the arts, he is known for large-scale, public projects that engage new audiences on difficult topics through the social science of comedy, games, theatre, and democratic participation.

Lambert is the co-founder and co-director of the Center for Artistic Activism, a research and training institute helping activists be more creative and artists be more effective.

As an artist, Lambert's work has been shown both nationally and internationally, from art galleries to Times Square to protest marches, featured in four documentary films and in over two dozen books, and collected by museums and rich people he does not relate to. Lambert has presented at the United Nations several times. His research is included in a United Nations report on the impact of advertising on cultural rights and is the basis for a book on popular understandings of capitalism.

Over the past six years he's focused on working with sex workers on campaigns for human rights, fighting for safe consumption spaces with people who use drugs like heroin and methamphetamine, and working with Treatment Action Group and Universities Allied for Essential Medicines in battling pharmaceutical companies to make life-saving medicines accessible and affordable for all. 